\title{
Rapid Procedure for Cloning of PCR Product and Sequencing with Automatic DNA Sequencer
}

\author{
Suguru MASHIMA ${ }^{1,2}$ and Masayuki SAKAGAMI ${ }^{2}$ \\ ${ }^{1}$ Laboratory of Racing Chemistry, 4-37-6, Kami-yoga, Setagaya-ku, Tokyo 158, and \\ ${ }^{2}$ Equine Research Institute, Japan Racing Association, 5-27-7, Tsurumaki, \\ Setagaya-ku, Tokyo 154, Japan
}

\begin{abstract}
A rapid and reliable procedure for molecular cloning and nucleotide sequencing of PCR product is described. PCR amplified fragment recovered from agarose gel by centrifugation through siliconized sterilized glass wool was further purified in sequential extraction with phenol, phenol/chloroform and chloroform. This was ligated into 'T'-hanged plasmid vector and transformed E. Coli was isolated. The plasmid recovered by the alkali denature method was purified by means of spun columns containing Sepharose CL-4B. This step is critical in obtaining a reading $>500$ bp with an automatic DNA sequencer.
\end{abstract}

Key words: cloning, horse, PCR, sequencing

\section{J. Equine Sci. \\ Vol. 5, No. 1, pp 33-36}

Innovation of the polymerase chain reaction (PCR) has revolutionized many fields of molecular biology, in particular isolation of genes and nucleotide sequencing $[2,3,4]$. Molecular cloning of PCR product is usually carried out by blunt-end ligation after this product was filled with dNTPs and klenow fragment or digestion with appropriate restriction enzymes before ligation. Although faithful, these methods are both time-consuming and cumbersome.

T-hanged vector is a convenient plasmid vector that is able to omit fill-in reaction for blunt-end ligation or restriction enzyme digestion to generate the cohesive ends. The vector was developed based on the characteristics that almost all PCR products have the adenyl tails in the 3' end of both strands. The vector is added with deoxythymidine triphosphate after plasmid is linearized by restriction enzyme digestion with Sma I or Eco R V to generate the blunt ends. This treatment leads thymine-adenine bondage between vectors and PCR products. We have cloned many PCR products by means of this technique, however the efficiencies were lower than that expected $(<60 \%)$.

This article was submitted August 2, 1993, and was accepted February 14, 1994.
So we refined the protocols to increase the efficiency. We examined the effects of purification of PCR products and the ratio of vector and insert in this study.

As automatic DNA sequencers became commercially available, the researchers anticipated that they were liberated from awkward procedures. Although automatic sequencers are less sensitive than conventional RI sequencing system, sometimes long range sequences are determined only with conventional RI protocols. The refinement of the sequencing protocols is needed for Automatic DNA sequencers as frequent operations. To this purpose, we also developed simple and reliable techniques to purify plasmid DNA for determination of long range sequences with an automatic DNA Sequencer (A.L.F. DNA Sequencer, Pharmacia LKB).

In the present study, we chose the equine interspersed element DNA as a target for PCR. One pair of primers (Primer a: 5'-CCAAACAGAGAGAATTTTCACAC-3' and Primer b: 5'-AAGAGTGCCCTGAACATAAAGA-3') was designed to amplify a $298 \mathrm{bp}$ fragment from equine genome. Thirty ng of genomic DNA was used for PCR amplification in $30 \mu \mathrm{l}$ of $10 \mathrm{mM}$ Tris. $\mathrm{Cl}(\mathrm{pH}$ 8.3), $50 \mathrm{mM} \mathrm{KCl}, 1.5 \mathrm{mM} \mathrm{MgCl} 2,0.001 \%$ (W/V) 
gelatin, each deoxynucleoside triphosphate at 200 $\mu \mathrm{M}, 60 \mathrm{pmol}$ of each primer and 1.25 $\mathrm{U}$ of Taq polymerase (Perkin-Elmer Cetus). Amplification was carried out for 30 cycles in the GeneAmp PCR system 9600 (Perkin-Elmer Cetus) (1 min, denaturation at $95^{\circ} \mathrm{C} ; 1 \mathrm{~min}$, annealing at $62^{\circ} \mathrm{C} ; 1$ min, elongation at $72^{\circ} \mathrm{C}$ ). After PCR products were electrophoresed in 2\% agarose gel (SeaKem GTG or Metaphor agarose, FMC), DNA fragments from the gel slices were recovered by centrifugation through the siliconized sterilized glass wool. This technique was originally described by Heery et al. [1]. Briefly, the gel slice was transferred to a punctured sterilized microcentrifuge tube in a two-tiered system. This was placed on top of another tube and centrifuged at $7000 \mathrm{rpm}$ for 15 min. The eluted samples were further purified by extraction of phenol, phenol/chloroform and chloroform, respectively. The optional steps for purification of PCR product did not alter the recovery of PCR product. We routinely recover over $30 \mathrm{ng}$ of PCR product from $30 \mu \mathrm{l}$ of PCR reaction. The purified PCR product (more than 6 ng) was ligated with $25 \mathrm{ng}$ of PCR $\mathrm{II}^{\mathrm{TM}}$ vector
(Invitrogen) at $12^{\circ} \mathrm{C}$ for $4 \mathrm{~h}$. We routinely used 20 $\mathrm{ng}$ of purified PCR product for a ligation. The ratio of vector and insert was estimated to $1: 10$ in this example. JM109 strain of E. Coli was transformed. The recombinant clones were selected in ampicillin/X-gal/IPTG containing LB plates and plasmid DNA was isolated by the alkali denature method as described by Sambrook et al. [5]. It was effective to extend the efficiency for cloning of PCR product. For example, Fig. 1 shows the results for plasmid DNA digested with Eco RI. Twenty-seven clones out of thirty contained appropriate length (300 bp) of inserts $(90 \%)$. The efficiency was thirty per cent higher than that of the previous protocol without purification of PCR products.

We have utilized conventional RI protocols to the nucleotide sequencing with an automatic DNA sequencer. In such experiments, we could not obtain the reproducible results. Because single strand phage DNA or ultra-centrifuged plasmid DNA were both good templates for the sequencing system, the impurity of template DNA was suspected for the major source of our failures. So we

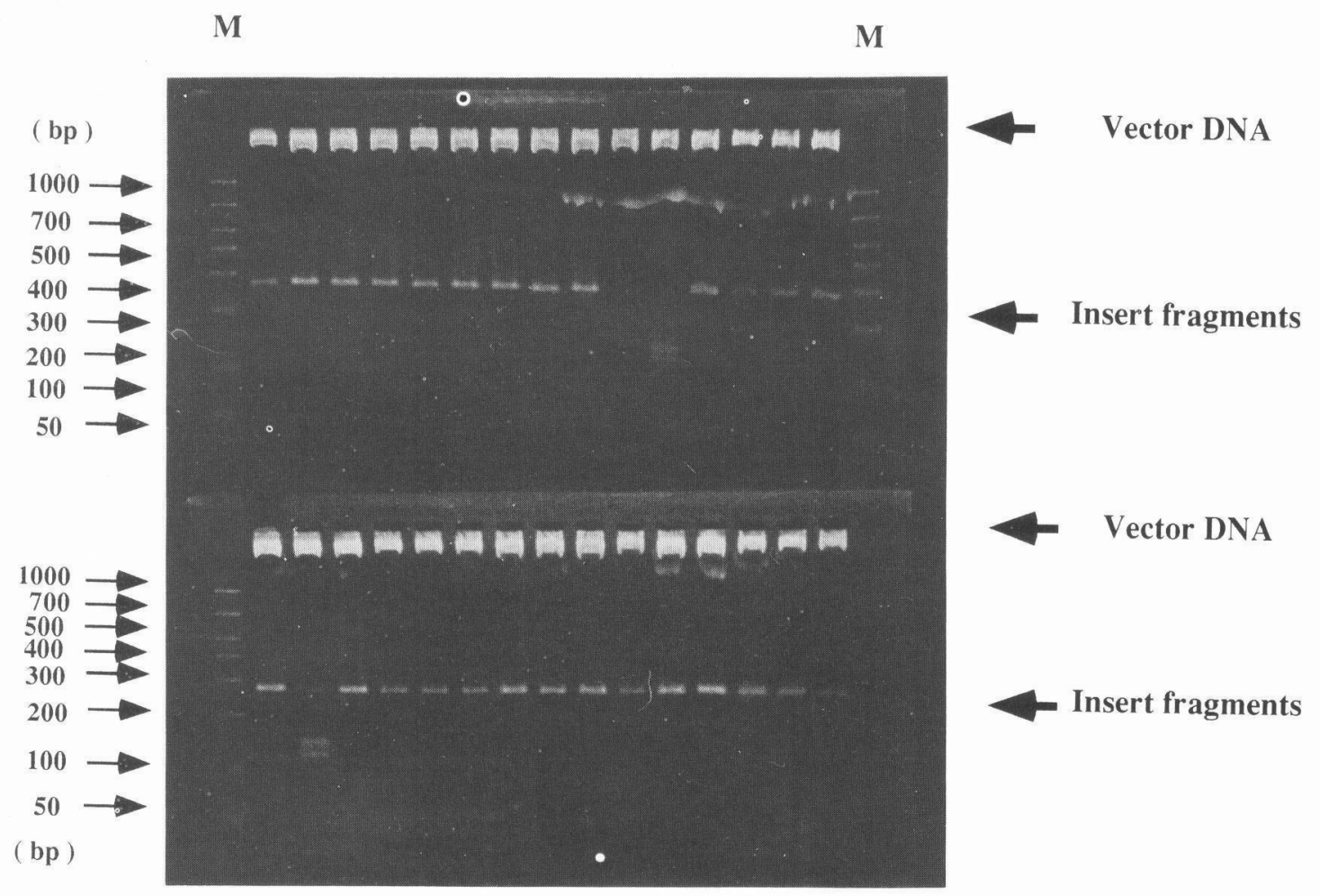

Fig. 1. Transformed E. Coli colonies were randomly picked up and were cultured at $37^{\circ} \mathrm{C}$ over night. Plasmid DNAs recovered from the cultures were digested with Eco RI. Then the samples were electrophoresed in 2\% agarose gel. M: molecular weight marker. 


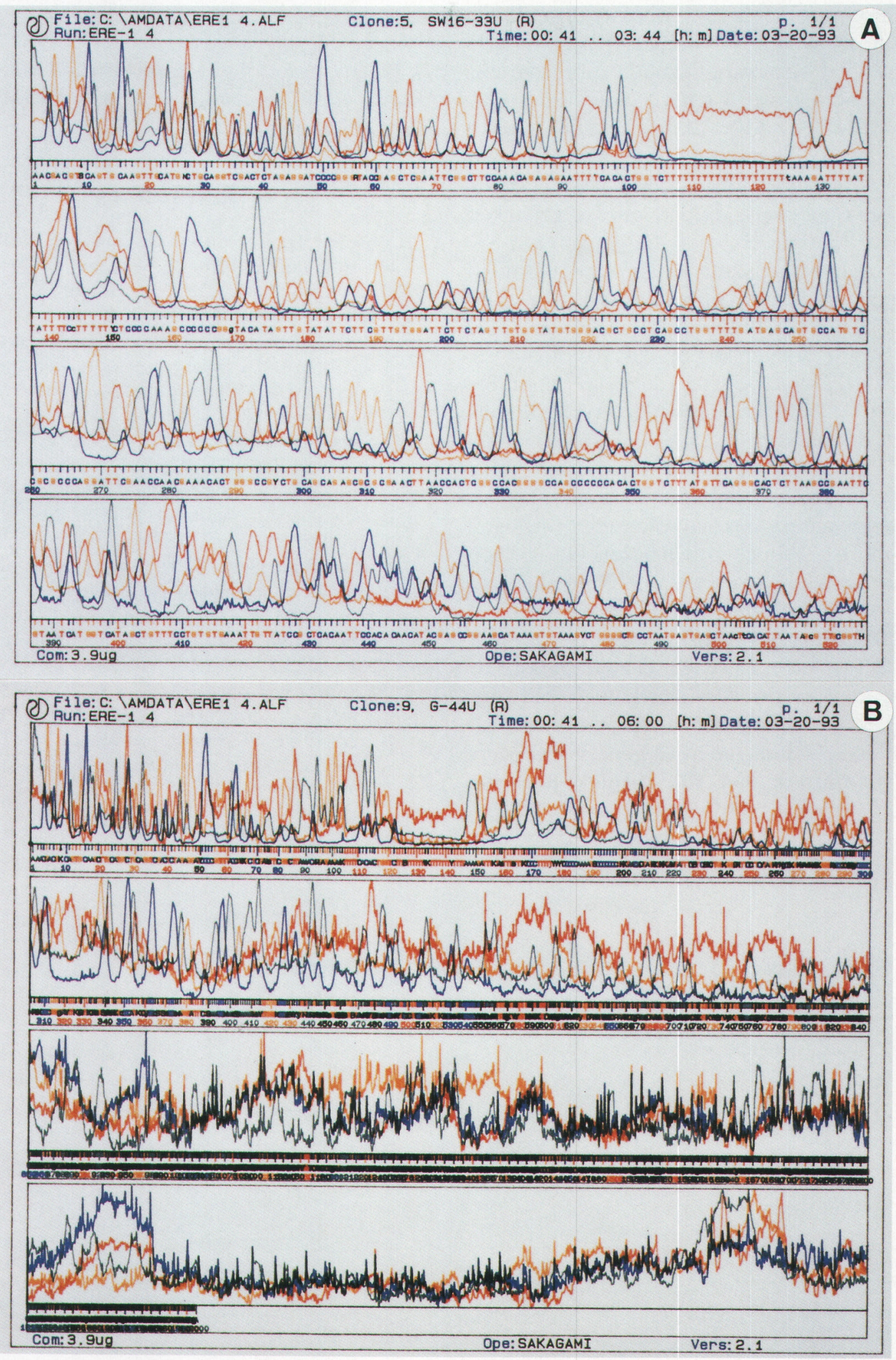

Fig. 2. Nucleotide Sequencing of equine short interspersed repetitive element (ERE-I) by means of two procedures (A and $\mathrm{B}$ ). In procedure $\mathrm{A}$, plasmid DNA recovered as described in the text were further purified with Sepharose CL-4B column and were used for sequencing template. Contrary to this, plasmid DNA processed as above except for gel filtration were used directly for nucleotide sequencing in procedure $\mathrm{B}$. 
attempted to purify plasmid DNA with a simple application. Plasmid DNA prepared as above was further purified by passing through spun columns containing Sepharose CL-4B. The resin suspended in STE $(10 \mathrm{mM} \mathrm{NaCl}, 1 \mathrm{mM}$ EDTA and 10 $\mathrm{mM}$ Tris $\cdot \mathrm{Cl}, \mathrm{pH} 7.5$ ) was poured into columns and centrifuged at $400 \mathrm{~g}$ for $2 \mathrm{~min}$. After crude plasmid solutions were dipped onto the packed resins, the columns were centrifuged again at 400 $\mathrm{g}$ for $4 \mathrm{~min}$. The eluted samples contained approximately $10 \mu \mathrm{g}$ of pure plasmid. The solution could be used directly as sequencing templates with AutoCycle sequencing kit or AutoRead sequencing kit (Pharmacia). This step was critical for a reading over $500 \mathrm{bp}$ (Fig. 2A-B). We routinely sequenced double strand DNA over 450 bp with a process. The protocols outlined here has some advantages to previous publications, e.g., (1) Cloning and sequencing steps are completed for just 3 days, (2) more sequence informations (450 to 500 base pairs routinely) are available from the process, (3) small cultures are enough to obtain template DNAs ( $<2 \mathrm{ml})$, (4) further purification of plasmid DNA such as CsCl centrifugation or PEG-precipitation is not required. It should contribute much to clinical and diagnostic investigation, such as in the detection of genetic disorders and the identification of viral strains in racing horses.

\section{Acknowledgment}

We are grateful to Ms. Murao and Ms. Yamakawa for technical assistance and to Dr. Mukoyama for critical reading.

\section{References}

1. Heery, D.M., Gannon, F. and Powell, R. 1990. A simple method for subcloning DNA fragments from gel slices. Trends. Genet. 6: 173.

2. Innis, T.M.A., Myambo, K.B., Gelfand, D.H. and Brow, M.A. 1988. DNA sequencing with Thermus aquaticus DNA polymerase and direct sequencing of polymerase chain reaction-amplified DNA. Proc. Natl. Acad. Sci. U.S.A. 85: 9436-9440.

3. Saiki, R.K., Bugawan, T.L., Horn, G.T., Mullis, K.B. and Erlich, H.A. 1986. Analysis of enzymatically amplified $\beta$-globin and HLA-DQ $\alpha$ DNA with allele-specific oligonucleotide probes. Nature 324: 163-166.

4. Saiki, R.K., Gelfand, D.H., Stoffel, S., Scharf, S.J., Higuchi, R., Horn, G.T., Mullis, K.B. and Erlich, H.A. 1988. Primer-directed enzymatic amplification of DNA with a thermostable DNA polymerase. Science 239: 487-491.

5. Sambrook, J., Fritsh, E.F. and Maniatis, T. 1989. Small-scale preparation of plasmid DNA, pp. 1.25-1-.28, In: Molecular Cloning: A Laboratory Manual, 2nd ed., Cold Spring Harbor Laboratory Press, New York. 